FACTA UNIVERSITATIS

Series: Law and Politics Vol. 15, N 3 , 2017, pp. 245 - 252

https://doi.org/10.22190/FULP1703245S

Review Article

\title{
SPECIFIC TREATMENT AND RIGHTS OF WOMEN DEPRIVED OF LIBERTY
}

UDC 343.8-055.26

\section{Milica Stanojević}

Law Office Jovanović, Niš, Republic of Serbia

\begin{abstract}
This paper discusses the rights of women prisoners as a special category of persons deprived of the fundamental human right - the right to liberty. The author focuses on women's rights in detention and in the course of serving a prison sentence. The specificities related to the status and treatment of women in conditions of social isolation are primarily attributable to their biological disposition. Quite often, they are pregnant or about to give birth, or already have children, in which case the protection of maternity is of crucial importance, particularly considering the fact that they are away from their home and family. One of the main problems in dealing with women's rights in general and in the Serbian penitentiary system in particular is the lack of sensitivity to the specific needs and psychology of women. In that context, the author refers to the conclusions of the European Committee for the Prevention of Torture and Inhuman and Degrading Treatment or Punishment.
\end{abstract}

Key words: women, penal institutions, prison, detention, maternity

\section{INTRODUCTORY REMARKS}

In the Republic of Serbia, the national legislation on the rights of persons deprived of liberty does not recognize the specific needs of certain categories of prisoners, including women in detention or those serving a sentence of imprisonment. Similarly, the administrative acts (by-laws) do not include specific provisions relating to the status and treatment of women deprived of liberty, even though the specific needs and psychological characteristics of this category of inmates calls for enacting special legislation on this matter. As there is no systemic act explicitly regulating the rights of women deprived of liberty, as a specific category of inmates with highly distinctive needs, the legislator should consider adopting a single systemic instrument which would take into consideration the distinctive features of women's treatment in penal institutions.

Received March $6^{\text {th }}, 2017 /$ Accepted June $26^{\text {th }}, 2017$

Corresponding author: Milica Stanojević, LL.M, Legal trainee

Law Office Jovanović, Niš, Republic of Serbia

E-mail: milica_stanojevic@ymail.com 
The institutional design and operating procedures in Serbian penal institutions corresponds to the male model, without taking into account the specific needs and the psychological profile of female prisoners. In addition, social isolation of mothers deprived of liberty has an extremely adverse impact on their children. Some studies have shown that the negative deviant child behavior is directly related to socially unacceptable behavior of the mother, especially if the child is deprived of mother's love and attention in infancy. The imprisoned or detained mothers are deemed to have failed twice: first, for breaching the law and, second, for failing to observe the social norms of acceptable behavior for women (Ignjatović, Ljubičić 2011: 62).

Considering women's biological disposition to bear children, women who are deprived of their liberty may be pregnant or parturient, or they may already have children. In this regard, the most difficult consequence of woman's deprivation of liberty is the separation from their children and the fact that they cannot take part in raising them. As a result, they are also deprivation of maternity (Špadijer Džinić, Pavićević, Simeunović-Patić, 2009: 230).

Besides, women deprived of their liberty often feel biologically "inferior", and they are prone to depression and emotional reactions to their isolation from the immediate social environment. Many women demonstrate variable emotions, ranging from denial to feelings of guilt and regret, which implies the need for appropriate psychological assistance. Notably, women deprived of liberty are highly susceptible to committing suicide, even five times more than free women and two times more than men who are serving a prison sentence. However, the recommendations of World Health Organization still do not define the profiles of women deprived of liberty who are at risk of attempting/committing suicide (Lečić-Toševski, 2005: 6).

Considering the fact that family life is one of the most important segment of woman's life, another significant problem is reflected in disturbed or disrupted family relations which necessarily calls for continuous treatment of all family members by relevant social institutions. The commitment and professional approach of different institutions and individuals shall facilitate the inmates' contacts with the family and the wider community.

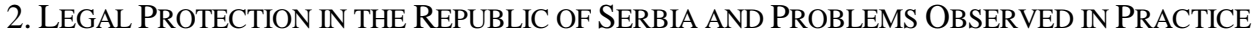

In the Republic of Serbia, the Act on the Execution of Criminal Sanctions ${ }^{1}$ regulates the procedure on the execution of criminal sanctions against adults, as well as the application of the detention measure. This Act envisages the rights and obligations of the persons subject to the imposed criminal sanctions as well as the organization of the Directorate for Execution of Criminal Sanctions. The Act equally applies to both men and women deprived of liberty, which also pertains to related administrative acts (bylaws). Thus, the provisions of normative acts applicable to all persons deprived of liberty are also applied in the treatment of detained or imprisoned women, except for certain areas regulating individual issues related to the specific position of women.

In the Republic of Serbia, there is only one penitentiary-correctional facility for women, which is located in Požarevac. It is a semi-open type of penal institution which has three wards: open, semi-open and closed. Although it is a semi-open type of institution, considering the architecture and the level of security, the Penitentiary-correctional facility for women in

\footnotetext{
${ }^{1}$ Act on the Execution of Criminal Sanctions (ECS Act), Official Gazette of Republic of Serbia, no.55/2014
} 
Požarevac corresponds to the standards established for penitentiary-correctional facilities of the closed type (i.e. maximum security prisons). It further means that the execution of a prison sentence, when it comes to women, is conducted in an inappropriate type of institution (Kostić, Ilić, 2015:330). Hence, penal and correctional facilities for women shall be designed and equipped to meet the specific needs of imprisoned women, which are quite different from the needs of male prisoners.

As for women in police custody, they are commonly detained in district prisons and penitentiary-correctional institutions admitting both male and female offenders, but they are usually located in a separate part of the same building. Female detainees should be provided special premises and separated from the male detainees. Moreover, considering the legal standard of the presumption of innocence, they should also be separated from the convicted offenders serving their prison sentences. For example, in the district prison in Belgrade, an entire detention block is reserved for detained women and juvenile detainees, with separate entrances, which precludes any possibility of physical contact between men and women. On the other hand, as already noted, women convicted to serve a term of imprisonment usually serve their sentences in the Penitentiary-correctional facility for women in Požarevac. Specifically, the categories of women who are referred to this penal institution include: convicted female offenders (both adults and juveniles) of Serbian nationality, regardless of the term (length) of the imposed prison sentence; female offenders sentenced in misdemeanor proceedings; all foreign female citizens and stateless women convicted to a prison sentence in criminal and misdemeanor proceedings; and female offenders convicted of criminal offenses involving elements of organized crime and war crimes (KonstantinovićVilić, Kostić, 2013: 56).

The allegations of ill-treatment of female detainees by male detainees are quite frequent, particularly in cases where the state fails to provide separate accommodation for women deprived of liberty and the female stuff to supervise such accommodation. According to the report issued by European Committee for the Prevention of Torture and Inhuman and Degrading Treatment or Punishment (CPT, 2000) ${ }^{2}$, some States have begun to make special arrangements for couples simultaneously deprived of their liberty to be accommodated together.

Further, women deprived of liberty must be admitted into the penal institution and searched by female officers. In domestic practice, the persons deprived of liberty should be searched only by staff of the same gender; if the search requires an inmate to undress, this procedure should exclude custodial staff of the opposite gender. The Helsinki Committee for Human Rights in Serbia expressed concern about the practice of allowing male prison officers access to units housing female detainees, which has led to the allegations of sexual abuse of women and the violation of their privacy. ${ }^{3}$

After being admitted and searched, every woman who is subject to detention or imprisonment should be examined by the doctor, and the medical findings shall be entered in the personal medical file (Art 71 ECS Act). It is the first health examination. According to Article 11 of the House Rules of penitentiary-correctional facilities and district prisons of

\footnotetext{
${ }^{2}$ European Committee for the Prevention of Torture and Inhuman or Degrading Treatment or Punishment Council of Europe, CPT standards, CPT/Inf/E (2002) 1 - Rev. 2015, retrieved from: http://www.cpt.coe.int/en/documents/engstandards.pdf (pp.94)

${ }^{3}$ Helsinki Committee for Human Rights in Serbia (2011), Penitentiary-Reformatory Facility for Women in Pozarevac, Monitoring the prison system reform, Belgrade, October 2011; retrieved from: http://www.helsinki.org.rs/doc/ zatvori\%20-\%20zene.pdf
} 
the Republic of Serbia ${ }^{4}$, the medical examination must be performed immediately, within 24 hours from admission at the latest. An institution doctor is also required to examine every convicted person on return to the institution from a leave of absence, as well as before release from the institution. The applicable rules do not provide for mandatory gynecological and psychological examination, nor do they prescribe the examination aimed at detecting the presence of some infectious diseases or the need to do some additional laboratory analysis, even though all these forms of medical examination may be highly valuable for their further institutional treatment.

According to the Act on the Execution of Criminal Sanctions, a woman who is six or more months pregnant, or has a child under the age of one (Article 50), is entitled to submit a petition for staying the execution within three days of receiving the order to report for serving the sentence (Article 61). The petitions to stay the execution of a prison sentence shall be submitted to the president of the competent basic court (Article 62). The petitioner shall supply the appropriate medical documentation which proves that the convicted woman has entered the sixth month of pregnancy. If the evidence is not provided with a petition, the president of the basic court will order the convicted person to provide the evidence within eight days, and caution the convicted person that the petition shall be denied if she fails to provide it (Art. 62, para 2). In the process of deciding on the petition in each case, the judge will take into consideration the type of committed criminal offence and the length of the imposed sentence of imprisonment, as well as a number of objective criteria: whether the convicted woman has children; how many children and how old they are; whether there is another person who can take care of them in the absence of their mother, etc. The most important subjective criterion for the judicial decision on the postponement of her prison sentence is the personality of the convicted pregnant woman. If the competent court accepts a petition for a stay of execution of her sentence, the convicted woman can remain free only until the child reaches age of three (Art. 59, para 1, item 2) In case of unfavorable decision, the convicted woman is obliged to start serving the imposed prison sentence when the court decision on the petitions to stay the execution of the prison sentence becomes final (Art. 65)

If a stay of execution was approved to a pregnant woman, and the child is stillborn, the stay shall be discontinued at the expiry of a period of six months after childbirth Also, if the child dies after birth, the stay shall be discontinued six months after the child's death. Where a stay of execution was approved to the mother of a child under the age of one year and the child dies, the stay shall be discontinued six months after the child's death (Art. 67, para 2).

As for the special protection of motherhood, the applicable Serbian legislation on the execution of criminal sanctions guarantees the convicted women the right to childbirth, free health care for the mother and her child by professional staff, and relevant accommodation in penal institution (Art. 120). The convicted woman may keep the child until he/she reaches the age of two, after which the parents shall consensually agree on whether the father, a relative or another person shall be given temporary custody of the child. If they cannot reach an agreement, the issue of child custody shall be decided by a competent court which has jurisdiction on the basis of the mother's permanent or temporary residence at the time of her conviction (Art. 119). In the absence of maternal care, children shall be accommodated

\footnotetext{
${ }^{4}$ House Rules in penitentiary-correctional facilities and district prisons of the Republic of Serbia, Official Gazette of RS, no.110/2014.
} 
in a special nursery room within the institution and provided professional care corresponding to the standards of infant nurseries (Art. 120).

Psychologists believe that the best solution for the child is to stay with the imprisoned mother until the age of two, which is considered to be the age when the child's need for socialization emerges. Although a former legal solution provided that the child could remain with the imprisoned mother until the age of one, the new legal solution is justified by the best interest of the child. After the child has reached the aged of two, it is necessary to devise mechanisms for gradual separation, which is considered to be in the child's best interests.

The domestic administrative regulation (House Rules of penal institutions) predicts that pregnant and parturient women, as well as women rearing children in prison, shall be accommodated apart from other female convicts. The premises for pregnant women and women with children must correspond to the standards of child care institutions. In the Women's Penitentiary-correctional facility in Požarevac, pregnant and parturient women are accommodated in a separate block, which is colloquially called "Childbirth Center"; the institutional physician and other professional staff are in charge of their nutrition and healthcare. Moreover, women's penal and correctional facilities are required to have special equipment facilitating the treatment of treating pregnant and parturient women, and female diseases. Considering the possibility of postpartum/post-natal distress, it is also important to provide appropriate psychological support to these women. After the children reaches the age of two, a convicted mother is entitled to a special visitation right: once in two months' time, she has the right to spend a period of time (no longer than 3 hours) with members of her family, including children and other close persons, in special premises provided by the institution.

When it comes to pregnant women detained in police custody, the domestic legislation does not contain specific provisions on this matter. When the delivery term approaches, the only possibility is to send the pregnant women to the nearest childbirth center, located in the same place where she is detained. Detained women should not be referred to the women's penal institution in Požarevac, given the fact that this institution accommodated only women who are convicted to serve a prison sentence. On the other hand, the problem of placing these women remains even after childbirth because there is a question where to accommodate a detained woman with her newborn child. One option would be to stay in the childbirth center as long as it is possible. Meanwhile, if the detention measure is still effective, the woman must go back to the institution where the detention is ordered (Milić, 2014:454).

\section{OPSERVATION OF THE EUROPEAN COMMITTEE FOR THE PREVENTION OF TORTURE AND INHUMAN OR DEGRADING TREATMENT OR PUNISHMENT}

The $10^{\text {th }}$ General Report of the European Committee for the Prevention of Torture and Inhuman and Degrading Treatment or Punishment (CPT, 2000) ${ }^{5}$ is dedicated to women deprived of their liberty. In this report, the CPT emphasized that women inmates represent a comparatively small minority of persons deprived of their liberty in all member states of the Council of Europe. Through this report, the CPT has indicated to the national authorities how to treat this special category of persons deprived of liberty.

\footnotetext{
${ }^{5}$ European Committee for the Prevention of Torture and Inhuman or Degrading Treatment or Punishment Council of Europe, CPT standards, CPT/Inf/E (2002) 1-Rev. 2015, retrieved from: http://www.cpt.coe.int/en/ documents/eng-standards.pdf (pp.93-96)
} 
As for the ante-natal and post-natal care provided in detention and in prison conditions, the CPT pointed out that it should be equivalent to care which is available in the outside community. On the ground of conducted research, the CPT concluded that the common practice in the Council of Europe member states is to transfer pregnant women prisoners to outside hospitals. It is also essential to meet the specific dietary needs of pregnant women prisoners, who should be offered food rich in proteins, fresh fruit and vegetables.

A special problem in prison conditions is the separation of imprisoned mothers from their young or new born children. On the one hand, the prison environment is certainly not appropriate for babies and children but, on the other hand, the forcible separation of mothers from their children is undesirable. Where they are held in custodial settings, it is important to provide a child-friendly environment and ensure normal movement and development of children's cognitive skills. Babies held in the prison environment should have adequate play and exercise facilities, as well as the opportunity to leave the institution and experience ordinary life outside its walls. The treatment of babies and young children in custodial settings should be supervised by specialists in social work and child development.

According to the CPT report, the burden of child-rearing should be shared, for example by the help of the child's father and other family members outside the penal institution. Where it is not possible, consideration should be given to providing access to crèche-type facilities (day childcare centers). Therefore, from the CPT's point of view, the governing principle in all cases should be the welfare of the child.

As for the hygiene and a health issues, the CPT stresses that women have the specific hygiene needs, significantly different from those of men. For women deprived of their liberty, it is important to provide access to sanitary and washing facilities, safe disposal arrangements for blood-stained articles, as well as provision of hygiene items, such as sanitary towels and tampons. Preventive health care measures and assistance of medical practitioners are also very important for women, especially preventive gynecological examination and screening for breast and cervical cancer. The contraceptive and "morning after" pills should be available to women deprived of their liberty under the same conditions as they are available to women who are free.

In order to prevent corroboration of outdated stereotypes of the social role of women, women deprived of liberty should enjoy access to meaningful activities in prison on an equal footing with their male counterparts. In practice, women are often offered traditional female activities (such as sewing or handicrafts), while male prisoners are offered training of a far more vocational nature. According to the CPT, denying women equal access to such activities could be qualified as discriminatory and degrading treatment. As for the women's penitentiary-correctional facility in Požarevac, the European Agency for Reconstruction implemented a valuable donation for education and vocational training of female prisoners: mini bakeries and computers for training of women prisoners.

The European Committee for the Prevention of Torture and Inhuman or Degrading Treatment or Punishment (CPT) sees the over-crowdedness of prisons as a serious problem in many states. Decreasing the number of prisoners would improve the conditions for serving prison sentences and bring many benefits. Working on the prisoners' re-socialization would be more substantial and would yield better results, and the organization within the institute itself would be improved and more rational, thus bringing multiple benefits for the society. ${ }^{6}$

\footnotetext{
${ }^{6}$ Helsinki Committee for Human Rights in Serbia (2011); http://www.helsinki.org.rs/doc/zatvori\%20-\%20zene.pdf
} 
Over the past decade, the Helsinki Committee for Human Rights in Serbia has been monitoring the prison system reform and identifying violations of fundamental human rights of marginalized and sensitive groups accommodated in various penal and correctional institutions. One of the institutions included in the research was the Penitentiary-correctional facility for women in Požarevac, as the only specialized prison for women in Serbia, even though women can also be placed in special detention units which are part of numerous penal and correctional institutions for execution of criminal sanctions. By monitoring this institution, the Helsinki Committee for Human Rights in Serbia concluded that the major problems are the lack of financial resources and inadequate living conditions in this institution, including bad hygiene and and sanitary conditions and unsatisfactory quality of health care services, given that prisoners often complained about the impossibility of obtaining analgesics in time. The Committee was also concerned about the absence of sensitivity to the specific needs of female inmates and women psychology, particularly taking into account that most women are displaced from their family environment. In particular, the Committee was concerned about inadequate treatment of victims of violence, persons with severe disabilities, elderly persons, and persons suffering from serious illnesses. The Committee also underscored a lack of inmates' occupational training and adequate professional engagement aimed at their re-socialization.

\section{CONCLUSION}

Although it is the only specialized institution in Republic of Serbia for the execution of criminal sanctions against women, the Penitentiary-correctional facility for women in Požarevac does not have a special treatment among the penal institutions, and has not received significant funding for the reconstruction of dilapidated buildings, which is absolutely necessary for its more efficient operation. The social standard of female prisoners is usually very low and their position in the conditions of social isolation is further aggravated by their displacement from the familiar environment and insufficient contact with their children and family. There are also additional negative effects of centralization of penal institutions in Serbia. Considering all these facts, instead of having one central institution for the execution of criminal sanctions for women, it would be a better solution to establish several smaller facilities in different parts of Serbia.

The monitoring of the prison system reform conducted by the Helsinki Committee for Human Rights in Serbia has shown that the major problems are the lack of financial resources and inadequate living conditions in penal and correctional facilities housing female prisoners. There is a particular concern about the absence of sensitivity to the specific needs of female inmates and women psychology, particularly taking into account that most women are displaced from their home, family and social environment.

Another problem is the quality of provided health care services, which is primarily due to the fact that the medical staff in penal institutions is considered as a part of the prison administration, which falls under the jurisdiction of the Ministry of Justice rather than under the jurisdiction of the Ministry of Health.

Another significant problem that the administration should work on is insufficient effort to improve the working and professional arrangements of women in prisons, who are commonly engaged in traditionally female manual and maintenance work, such as handicrafts, sewing, farming activities, and workshop activities organized by the institution. 
In conclusion, the best solution for improving the position, rights and institutional treatment of women deprived of liberty would be the adoption of a single comprehensive legislative act on this matter which would be based on the specific needs of detained and imprisoned women, in full observance of their biological and psychological structure.

\section{REFERENCES}

Ignjatović Đ., Ljubičić. M. (2011), Žene i zatvor: Opšta pitanja i studija slučaja (Women and prison: General issues and case studies), Anali Pravnog fakulteta u Beogradu 1/2011, Beograd

Kostić M., Ilić I. (2015), Žene osuđenice-o kriminološkom diskursu i penološkom tretmanu (Women convicts: criminological discourse and penal treatment), Pravna riječ - Udruženje pravnika Republike Srbije br. 44

Konstantinović-Vilić S., Kostić M. (2013). Sistem izvršenja krivičnih sankcija i penalni tretman u Srbiji, (Execution of Criminal Sanctions and Penal Treatment in Serbia), Niš: Pravni fakultet, 2013, str. 56

Lečić-Toševski D. (2005), Mentalni poremećaji i poremećaji ponašanja (Mental disorders and behavioral disorders), Institut za mentalno zdravlje, Beograd

Milić I. (2014), Specifičnosti odlaganja izvršenja kazne zatvora i primene mere pritvora s obzirom na trudnoću i ličnost žene (Specificities of staying the execution of a prison sentence and applying the detention measure with reference to pregnancy and woman's personality), Zbornik radova Pravnog fakulteta u Novom Sadu, Vol. 48 br. 2., Novi Sad

Pravilnik o kućnom redu kazneno popravnih zavoda i okružnih zatvora Republike Srbije (House Rules in penitentiary-correctional facilities and district prisons of the Republic of Serbia), Sl.glasnik RS br.110/2014

Špadijer-Džinić J., Pavićević O., Simeunović Patić B., (2009), Žena u zatvoru - deprivacije zatvoreničkog života (Women in prison: deprivations of life in prison), Institut za kriminološka i sociološka ispitivanja, Beograd

Zakon o izvršenju krivičnih sankcija Republike Srbije (Act on the Execution of Criminal Sanctions of the Republic of Serbia) „Sl. glasnik RS“ br. 55/2014

Online sources:

1. European Committee for the Prevention of Torture and Inhuman or Degrading Treatment or Punishment Council of Europe, CPT standards, CPT/Inf/E (2002) 1 - Rev. 2015, retrieved from: http://www.cpt.coe. int/en/documents/eng-standards.pdf

2. Helsinki Committee for Human Rights in Serbia (2011), Penitentiary-Correctional Facility for Women in Pozarevac, Monitoring the prison system reform, Belgrade: retrieved from: http://www.helsinki.org.rs/ doc/zatvori\%20-\%20zene.pdf

\section{SPECIFIČNOSTI TRETMANA I PRAVA ŽENA LIŠENIH SLOBODE}

Predmet ovog rada su prava žena lišenih slobode $i$ tretman ove specifične kategorije lica lišenih svog osnovnog prava - prava na slobodu. Pri tome, akcenat je na pravima žena u pritvoru $i$ onih koje su osuđene na kaznu zatvora. Naravno, specifičnosti vezane za položaj i tretman žena u uslovima socijalne izolacije se pre svega povezuju sa njihovom biološkom određenošću, jer se neretko radi o majkama, trudnicama i porodiljama. Stoga je zaštita materinstva od suštinskog značaja, naročito s obzirom na činjenicu da je većina žena daleko od svog doma i porodice. Ono što se uočava kao jedan od najvećih problema u sistemu izvršenja krivičnih sankcija u Republici Srbiji, a i generalno, je izostanak senzibiliteta za specifične potrebe i psihologiju žena. U tom kontekstu, autor se osvrće na zaključke Evropskog odbora za sprečavanje mučenja i neljudskog ili ponižavajućeg postupanja ili kažnjavanja (CPT).

Ključne reči: žene, penitencijalne ustanove, zatvor, pritvor, materinstvo

Proofreading and translation: Gordana Ignjatović 